Bottom Line Results from

Strategic Human Resource Planning 


\section{Bottom Line Results from Strategic Human Resource Planning}

Edited by

\section{Richard J. Niehaus}

Assistant for Human Resources Analysis

Office of the Chief of Naval Operations

Washington, D.C.

and

Karl F. Price

Principal

TPF \&C, a Towers Perrin Company

Philadelphia, Pennsylvania

Springer Science+Business Media, LLC 


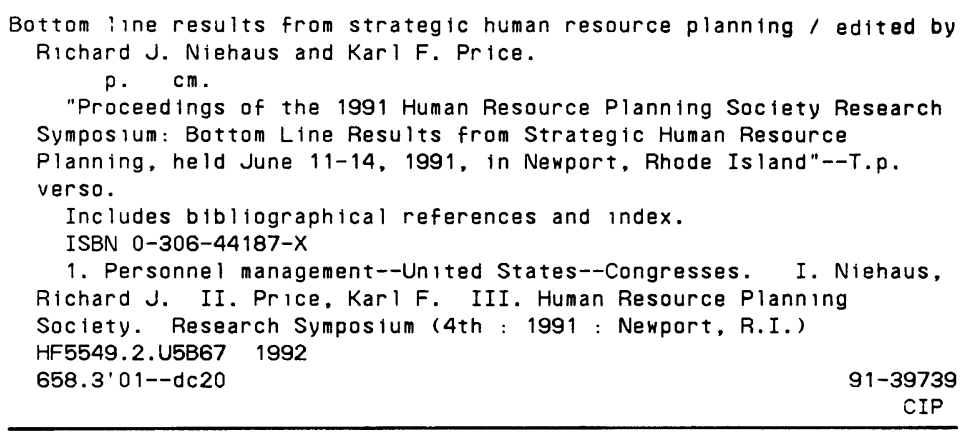

Proceedings of the 1991 Human Resource Planning Society Research Symposium: Bottom Line Results from Strategic Human Resource Planning, held June 11-14, 1991, in Newport, Rhode Island

ISBN 978-1-4757-9541-7

ISBN 978-1-4757-9539-4 (eBook)

DOI 10.1007/978-1-4757-9539-4

(C) Springer Science+Business Media New York 1991

Originally published by Plenum Press, New York in 1991

Softcover reprint of the hardcover 1 st edition 1991

All rights reserved

No part of this book may be reproduced, stored in a retrieval system, or transmitted in any form or by any means, electronic, mechanical, photocopying, microfilming, recording, or otherwise, without written permission from the Publisher 


\section{Preface}

This volume is the proceedings of a symposium entitled "Bottom Line Results from Strategic Human Resource Planning" which was held at Salve Regina University, Newport, Rhode Island on June 11-14, 1991. The meeting was sponsored by the Research Committee of the Human Resource Planning Society (HRPS).

In developing the agenda, the Research Committee continued the approach used in previous HRPS research symposia. The focus of these meetings is on the linkage of the state-of-practice with the state-of-the-art. Particular attention was placed on research studies which were application oriented so that member organizations can see examples of ways to extend current practices with the knowledge presented by the applications.

The meeting had sessions on: (1) The Strategic Role of Human Resources, (2) Globalization, (3) Downsizing, (4) Quality as a Strategic Human Resource Issue, (5) Forecasting Human Resource Needs, and (6) Managing People to Build Competitive Advantage. Twenty six papers were presented with discussion periods at appropriate points in the meeting. This volume contains twenty two of these papers along with an introductory paper. A short summary is also provided at the beginning of each major subdivision into which the papers are arranged.

Thanks are in order for all who contributed to the success of the meeting. First, acknowledge should be given to the members of the Research Committee who provided assistance in preparing for the meeting and in reviewing the papers which appear in this volume. These research committee members include: Lee Dyer, Charles Fay, Normand Green, Walter Griggs, Gerald Groe, Michael Hawkins, Richard Niehaus, Karl Price, David Schweiger, Carol Schreiber, and Jo Ann Verdin. Excellent help through all phases of the development and execution of the meeting was provided by the HRPS Executive Director, Steve Noble. Helpful suggestions concerning the proceedings as well as with meeting arrangements were ably provided by Joan Kasper, Ellen Gordon and other members of the HRPS staff.

Helpful editorial assistance was provided by Patricia Vann at Plenum Press in all phases of the development of this volume. Very helpful suggestions concerning the layout and production of the book was provided by Gregory Safford at Plenum.

Particular thanks should be given to the Chairman of the Research Committee, Normand Green. A special debt is owed to Salve Regina University which provided for every need during the course of the symposium. Special appreciation is due to our wives for their patience and encouragement.

Richard J. Niehaus

Karl F. Price 


\section{Contents}

\section{Introduction}

Introduction . . . . . . . . . . . . . . . . 1

N.W. Green

\section{Strategic Human Resource Issues}

Strategic Human Resource Issues: Perceptions of the

Human Resource Planning Society Corporate Sponsors . . .

K.F. Price

Building Local Labor Market Dynamics into Workforce 2000 . . . .

D.M. Atwater, J.A. Nelson, and R.J. Niehaus

Developing the Human Resource Executive as a Strategic

Partner: Turning Concept into Reality . . . . . . . . . . . .

R.S. Koster and D.M. Schweiger

Powerful Partnerships: Linkages between HR and

Strategic Business Activities in the Delaware Valley. . . . .

D.W. Danner

\section{Empowering People at the Workforce Level}

Focusing Bordon Employees on Continuous Improvement. . . . . .

A.L. Miller, J.H. Head, and B. Thomas

The Bottom Line of Empowerment. . . . . . . . . . . . . . . .

W.H. Griggs and S.L. Manring

Management Practices Leading to High Work Unit

Performance ...................

K.N. Gaertner and S.D. Nollen

\section{Restructuring/Right-sizing}

Management of a Major Downsizing at a Naval Shipyard . . . . . .

Voluntary Excessing Employees: The Right Way

to Downsize an Organization. . . . . . . . . . . . . .

R. B. Stonaker

Implementing Organizational Change: An Ordinary Effort

for an Extra-ordinary Situation . . . . . . . . . . . . . 


\section{Managing People}

A Cross Cultural Study of Managerial Attitudes toward

Executive Development: Implications for

Transnational Organizations . . . . . . . . . . . .

M.E. Beres, J.D. Portwood, M.A.S. Latib, M.J. Timmons, and J.M. Chowdhury

Hourly Training Needs: The Bottom Line Reaches

the Leading Edge . . . . . . . . . . . . . . .

181

P.N. Blanchard

The Industrial Adjustment Service: A Canadian Model

for Change Management . . . . . . . . . . . . .

J. Butcher

Employee Pay Plan Preferences in a Bank . . . . . . . . . . . 205

T.J. Atchison and C. Zumberge

Employee Commitment: The Elusive Edge. . . . . . . . . . .

P.L. Bugbee and D.J. Davis

\section{Measuring the Impact on the Bottom Line}

Defining Effectiveness and Efficiency Measures in the Context

of Human Resource Strategy . . . . . . . . . . . . . .

235

J.W. Walker and T.P. Bechet

Why Measure the CEO's Performance. . . . . . . . . . . . . . .

247

C.E. Schneier, R.W. Beatty and D.G. Shaw

Company Values: A Key to Managing in Turbulent Times . . . . .

D.J. McLaughlin, B.C. McLaughlin and C. Wilcox Lischick

Quality of Output Programs for Manufacturing

and Service Industries . . . . . . . . . . . . .

J.A. Verdin and A. Pagano

Workforce Analysis and Turnover Forecasting: Building

Capacity in New York State Government . . . . . . . . . . .

C.L. Teigland

Survey Data as a Catalyst for Employee Empowerment and Organizational Effectiveness . . . . . . . . . J.R. Hinrichs

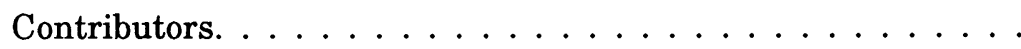

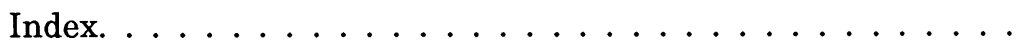

